managed oral anticoagulation therapy. CMAJ 2006;I74(I3): $1847-52$

2. Fitzmaurice DA, Gardiner C, Kitchen S, et al. An evidence-based review and guidelines for patient self-testing and management of oral anticoagulation. BrJ Haematol 2003;131:156-165.

DOI:Io.1503/cmaj.I060232

\section{Avascular necrosis}

\section{after a steroid injection}

I read with interest the Clinical Vista Brief about bilateral hip avascular necrosis. ${ }^{1}$ I note that the corticosteroid injection was given 8 months before the condition was diagnosed, but the patient had complained of hip pain for I3 months. Cortisone injections (particularly bursa and tendon sheath infiltrations) are extremely common treatments in primary care, but avascular necrosis is rarely seen. Although one always has to be careful when using steroid infiltrations, they are usually quite safe. In this particular case, the connection between the cortisone injection and the development of avascular necrosis is not clear, given the chronology of events.

\section{Pierre Juéry}

Assistant Professor

Department of Family Medicine

University of Ottawa

Ottawa, Ont.

\section{REFERENCE}

I. Gunal I, Karatosun V. Avascular necrosis of the femoral heads after single corticosteroid injection. CMAJ 2006;175(I):3I.

DOI:Io.1503/cmaj.Io6or65

\section{[The authors respond:]}

We thank Pierre Juéry for his interest in our report on avascular necrosis of the femoral heads. ${ }^{1}$ We would like to clarify the chronology of events: the patient's symptoms appeared 8 months after the corticosteroid injection; the MRI scan was done 5 months after the onset of the symptoms or in other words 13 months after the corticosteroid injection. Because the time to symptom onset fits with other reports in the literature, and we excluded all other known causes of avascular necrosis of the hip, it is our opinion that all patients should be warned about the risk associated with even a low dose of corticosteroids.

\section{Izge Gunal}

Vasfi Karatosun

Department of Orthopedics

Dokuz Eylul University Hospital Izmir, Turkey

\section{REFERENCE}

I. Gunal I, Karatosun V. Avascular necrosis of the femoral heads after single corticosteroid injection. CMAJ 2006;175(I):3I.

DOI:Io.I503/cmaj.Io60233

\section{Letters submission process}

CMAJ's enhanced letters feature is now the portal for all submissions to our letters column. To prepare a letter, visit www.cmaj.ca and click "Submit a response to this article" in the box near the top right-hand corner of any CMAJ article. All letters will be considered for publication in the print journal.

Letters written in response to an article published in $C M A J$ are more likely to be accepted for print publication if they are submitted within 2 months of the article's publication date. Letters accepted for print publication are edited for length (usually 250 words) and house style.

\section{Mécanisme de présentation des lettres}

Le site amélioré des lettres du JAMC est désormais le portail de réception de tous les textes destinés à la chronique Lettres. Pour rédiger une lettre, consultez un article sur le site www.jamc.ca et cliquez ensuite sur le lien «Lettres électroniques : répondre à cet article», dans la boîte en haut à droite de l'article. Toutes les lettres seront étudiées pour une éventuelle publication dans le journal imprimé.

Les lettres répondant à un article publié dans le JAMC sont plus susceptibles d'être acceptées pour publication imprimée si elles sont présentées dans les deux mois de la date de publication de l'article. Les lettres acceptées pour publication imprimée sont révisées en fonction du style du JAMC et raccourcies au besoin (elles doivent habituellement compter au maximum 250 mots). 